\title{
55. HYDROTHERMAL ACTIVITY IN THE GUAYMAS BASIN, GULF OF CALIFORNIA: A SYNTHESIS ${ }^{1}$
}

Joris M. Gieskes and Miriam Kastner, Scripps Institution of Oceanography, La Jolla, California

Gerhard Einsele, Geologisches Institut der Universität Tübingen, 74 Tübingen, Federal Republic of Germany

Kerry Kelts, Eidgenössische Technische Hochschule, Geologisches Institut, Zürich, Switzerland

and

Jeffrey Niemitz, Department of Geology, Dickinson College, Carlisle, Pennsylvania

\begin{abstract}
Observations of the physical properties of sediments, the chemistry of interstitial waters and solid phases, the mineralogy of the sediments, and the isotope geochemistry of interstitial waters and sediments have led to the conclusion that two types of hydrothermal systems are operative in the Guaymas Basin of the Gulf of California: (1) hydrothermal activity associated with relatively shallow basaltic sill intrusions in highly porous sediments-generally of relatively short duration and associated with temperatures $<200^{\circ} \mathrm{C}$-and (2) hydrothermal activity caused by large magmatic intrusions at greater depths. This latter activity involves recharge of the hydrothermal system by basin bottom waters; fractures in low-porosity sediments and faults in the sea floor serve as conduits for fluids heated up to temperatures in excess of $300^{\circ} \mathrm{C}$. This type of hydrothermal activity lasts long enough to lead to substantial alteration of sediments into a well-developed greenschist facies: chlorite-quartz-albite-sphene-epidote-Fe-sulfides. The mechanisms of the hydrothermal systems are discussed in detail and are consistent with the extensive heat flow data obtained in this area.
\end{abstract}

\section{INTRODUCTION}

In order to explain heat flow anomalies near oceanic spreading centers, the interaction between upwelling hot magmas and downward-flowing ocean water has been invoked by various authors (Lister, 1972; Sclater and Klitgord, 1973; Williams et al., 1974; Wolery and Sleep, 1976; Anderson et al., 1977, 1979). Subsequently, hydrothermal vents have been discovered in the Galapagos Rift (Corliss et al., 1979), on the East Pacific Rise at $21^{\circ} \mathrm{N}$ (Francheteau et al., 1979; Spiess et al., 1980), and at other oceanic spreading centers. Chemical analyses of hydrothermal waters emanating from vents at the Galapagos Rift, as well as of those obtained at $21^{\circ} \mathrm{N}$, indicate profound changes in chemical composition of these waters when compared to the original sea water (Corliss et al., 1979; Edmond et al., 1979a, b, c), similar to those observed in hydrothermal sea water-igneous rock interaction experiments (Bischoff and Dickson, 1975; Hajash, 1975; Menzies and Seyfried, 1979; Mottl and Holland, 1978; Seyfried and Bischoff, 1977). Associated with such hydrothermal activity are metal-rich deposits of various composition (Boström and Peterson, 1965; Francheteau et al., 1979; Haymon and Kastner, 1980; Moore and Vogt, 1976; Natland et al., 1979; Scott et al., 1974).

These observations have been made in environments typical of mature oceanic spreading ridges, that is, in areas of low sedimentation rates, where basalts are exposed to the ocean. In this report, however, we wish to describe hydrothermal activity in the Guaymas Basin of

\footnotetext{
${ }^{1}$ Curray, J. R., Moore, D. G., et al., Init. Repts. DSDP, 64: Washington (U.S. Govt. Printing Office).
}

the Gulf of California (Fig. 1), which is more representative of the initial stages of ocean evolution. Here basaltic magma forming new oceanic basement intrudes as sills into rapidly deposited soft sediments, thus creating a basement quite different from the normal ophiolite model (Moore, 1973; Einsele et al., 1980; Einsele, this volume, Pt. 2).

Prior to the drilling program in the Guaymas Basin (Fig. 1), evidence for hydrothermal circulation in this area was obtained from intensive heat flow surveys (Lawver et al., 1975; Williams et al., 1979). The extremely local distribution of areas of high heat flow (Fig. 1) was interpreted in terms of basaltic intrusions. Hydrothermal deposits were discovered in the northern trough of the basin (Fig. 1) and have been described by Lonsdale (1978; Lonsdale et al., 1980). Since the Leg 64 drilling program, extensive hydrothermal deposits have been mapped in August 1980 in the southern trough (Lonsdale, pers. comm.) and sulfide deposits have been sampled in the same area by Alvin dives in January 1982.

Essentially the hydrothermal system in the Guaymas Basin, which we describe in this report, is one of a series of hydrothermal systems associated with the East Pacific Rise and the extension of this spreading system into the Gulf of California and the Imperial Valley of Southern California. Whereas at $21^{\circ} \mathrm{N}$ on the East Pacific Rise hydrothermal solutions emanate directly from the basalts, in the Guaymas Basin the high-temperature fluids stem from interactions of sea water and sediment interstitial waters with heated sediments and with basaltic lavas. In the Imperial Valley of Southern California and Mexico, magmas penetrate into terrigenous sediments and hydrothermal waters originate by advection of meteoric waters into the system (Elders, 1979). 

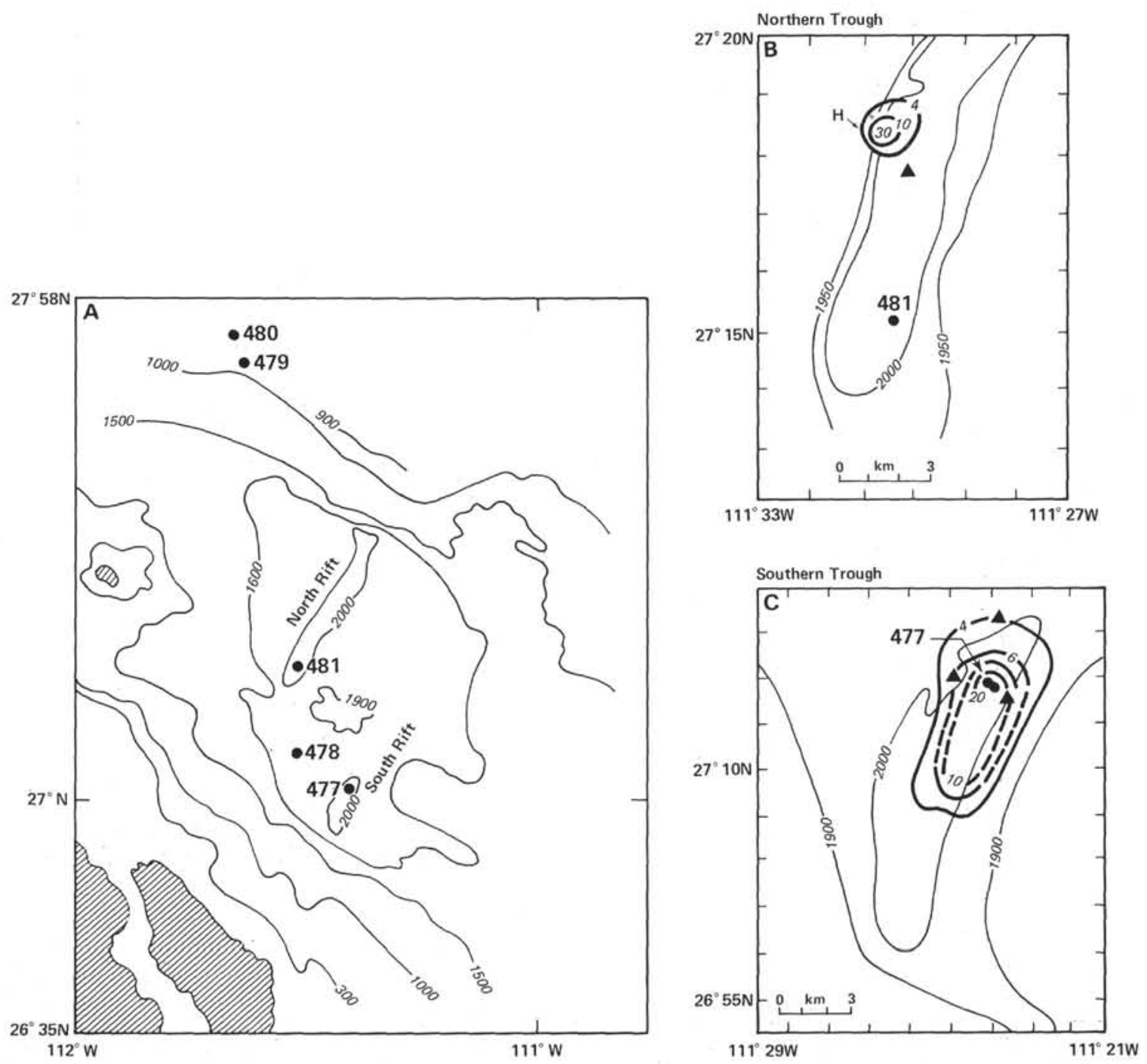

Figure 1. Map of Guaymas Basin (A), with details of northern rift (B) and southern rift (C). Depth contours in meters; numbers indicate DSDP sites; heat flow contours (thick lines) in $\mathrm{HFU}\left(10^{-6} \mathrm{cal} \mathrm{cm}^{-2} \mathrm{~s}^{-1}\right)$; triangles are topographic highs; $\mathrm{H}=$ hydrothermal deposit (Lonsdale, 1978; Lonsdale et al., 1980) near heat flow anomaly of 31 HFU in northern rift (Williams et al., 1979).

Although sill intrusions have previously been noticed in deep-sea drilling studies, their effects on surrounding sediments have not received much attention. A notable exception to this, of course, is the study of the organic geochemistry of sediments near a basaltic sill intrusion at Site 268, DSDP Leg 41 (Baker et al., 1978; Simoneit et al., 1981). In the Guaymas Basin, where sill intrusions occur now or have occurred in the recent past (Einsele et al., 1980; Lonsdale, pers. comm.), there arose an excellent opportunity to study their effect on the physical properties of the sediments, the mineralogy and chemistry of the solid phases, and the chemistry of the connate waters.

In this chapter we discuss the nature of the hydrothermal systems operative in the Guaymas Basin on the basis of our observations during DSDP Leg 64. Detailed background data can be obtained from other chapters by Gieskes, et al., Kastner, Einsele, Kelts, and Niemitz (this volume, Pt. 2). Here we first summarize these observations and then undertake a general discussion of the nature of the hydrothermal systems. The effects of the basaltic sill intrusions on the organic geochemistry of the sediments at these sites are summarized by Simoneit (this volume, Pt. 2).

\section{LITHOLOGY OF GUAYMAS BASIN SITES 477, 478, AND 481}

In this chapter we focus mainly upon Sites 477 and 481 , both located in the actual spreading troughs, but Site 478 is also of interest, in that it is located near the transform fault connecting the active spreading troughs (Fig. 1). The lithologies of Sites 477,478 , and 481 are given in Figure 2. Note in particular the occurrence of sill intrusions in all three of these sites. Heat flow at Site 477 is higher than $20 \mathrm{HFU}$ (1 HFU [heat flow unit] = $10^{-6} \mathrm{cal} \mathrm{cm}^{-2} \mathrm{~s}^{-1}$ ), whereas at Site 481 a heat flow of $\sim 4 \mathrm{HFU}$ and at Site 478 a heat flow of $3.65 \mathrm{HFU}$ were measured.

The sediments in this area are generally characterized by rapidly deposited diatomaceous oozes and clays, tur- 


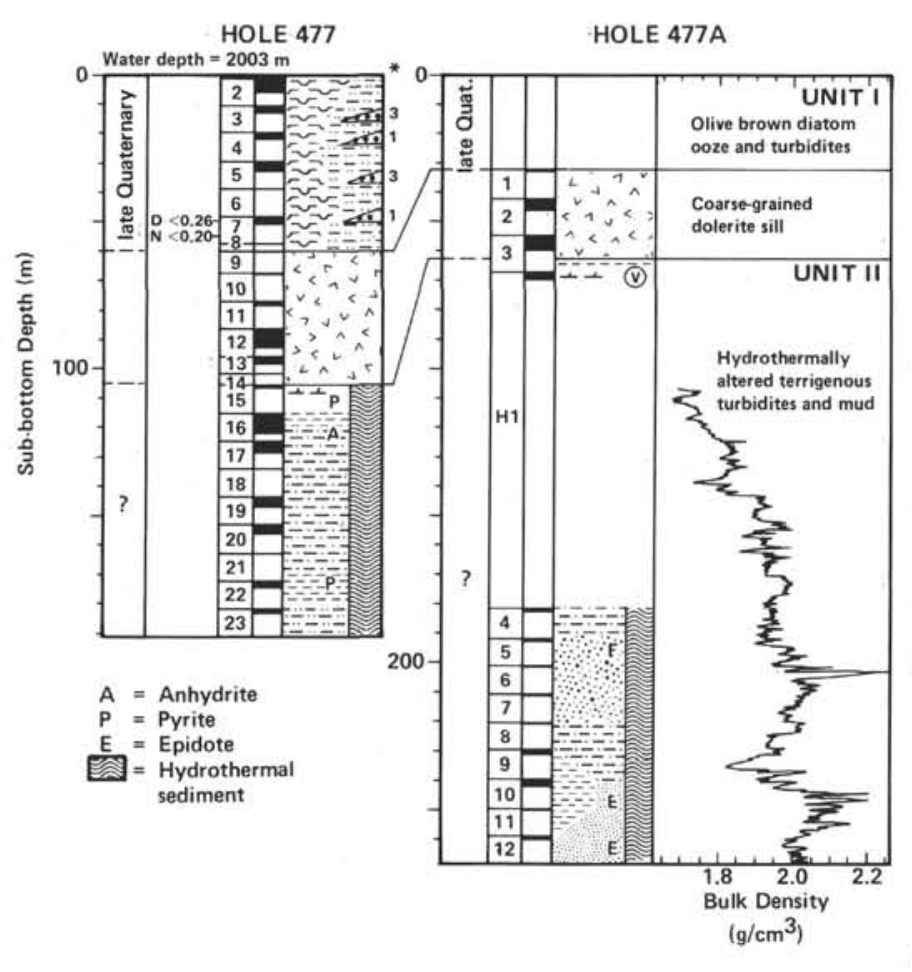

Figure 2. Lithology of Sites 477, 478, and 481, Guaymas Basin.
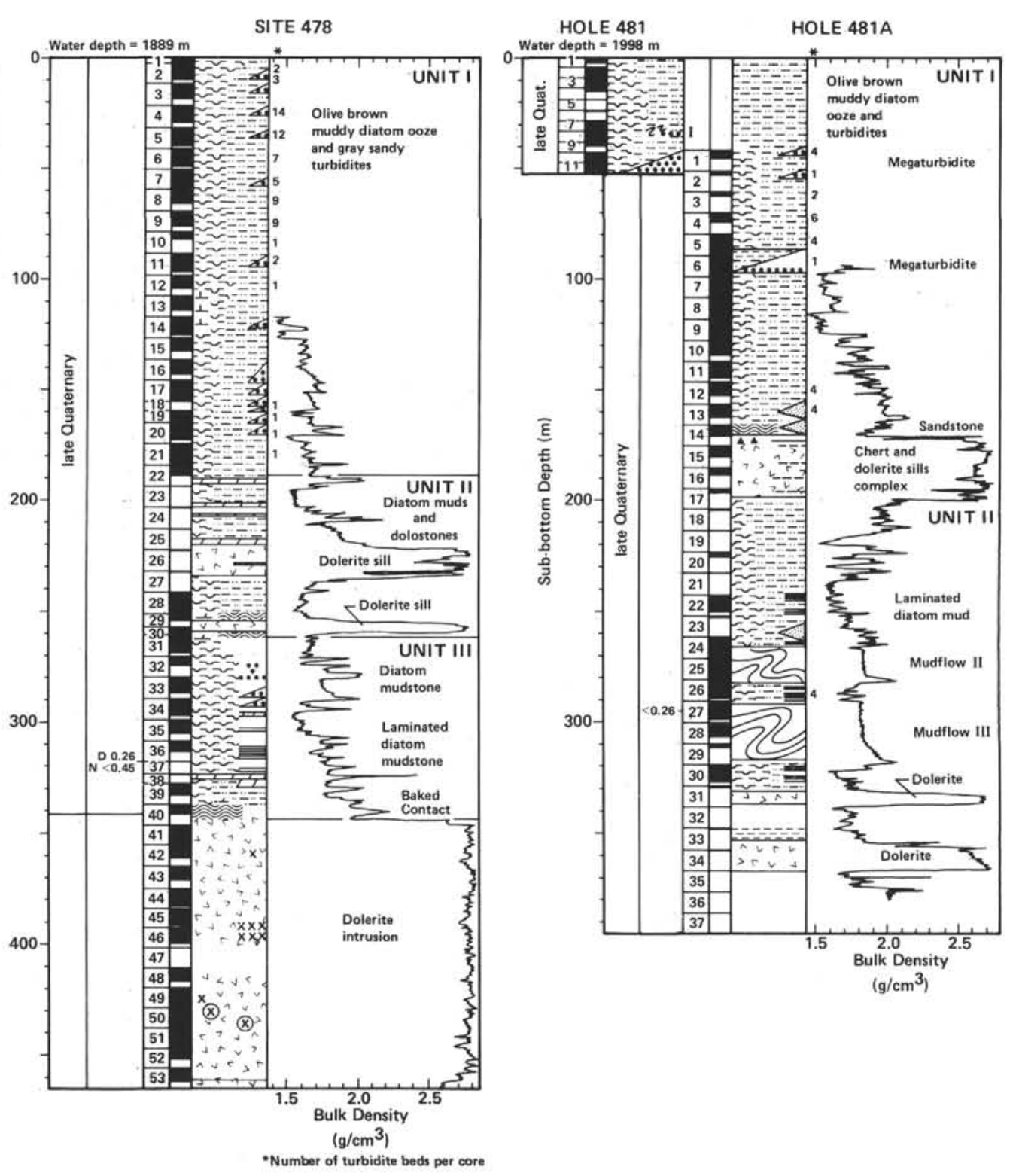
bidites, and mudflows. Intrusions of dolerite sills have subsequently altered these sediments during and shortly after emplacement of the sills. Large changes in porosity above and below the sills attest to the fact that the layers of dolerite are sill intrusions rather than basalt flows deposited on top of the sediments (Einsele et al., 1980). At both Site 477 and Site 481 , contact metamorphism has affected the sediments above and below the sill intrusions. At Site 477, below the upper sill complex, extensive hydrothermal activity has led to the formation of greenschist facies rocks (Fig. 2).

These observations on the thermal alteration of the sediment have led us to postulate that two types of hydrothermal systems are operative in the Guaymas Basin spreading troughs (Kastner and Gieskes, 1981):

1) Hydrothermal activity associated with the emplacement of dolerite sills into highly porous sediments, and

2) Hydrothermal activity associated with large-scale magmatic intrusions under a relatively thick sediment cover.

In the following sections we describe the characteristics of these hydrothermal systems.

\section{PHYSICAL PROPERTIES}

Einsele (this volume, Pt. 2) describes careful studies of the physical properties of the sediments in the Guaymas Basin and notes in particular large decreases in porosity near the sill intrusions (Fig. 3). Einsele et al. (1980) and Einsele (this volume, Pt. 2) estimate the volume of pore waters that must have been expelled as a result of the thermally induced convection and suggest that the reduction in sediment thickness is roughly equivalent to the thickness of the sills. The important points for our discussion are that large-scale migration of interstitial waters away from the sill intrusions does occur and also that the zones above the sills over which porosities appear to be affected probably represent the minimum thickness of the sediments present at the time the sill intruded. This implies that sills penetrate into these sediments at depths of at least $10-50$ meters below the sediment/water interface. In turn, this means that this water must have been expelled off the sediments and into the basin bottom waters, presumably along faults, rifts, and fissures or along the basin fault scarps.

\section{INTERSTITIAL WATER CHEMISTRY}

A detailed description of the interstitial water chemistry of Sites 477,478 , and 481 is presented by Gieskes et al. elsewhere in this volume, Pt. 2. Here we emphasize the observations relevant to high-temperature interactions between the dolerite sills and heated sediments and the interstitial waters of the sediments. Figure 4 presents the chemistry of the interstitial waters for Sites 477 and 481.

At Site 477 , where hydrothermal activity still continues, gradual increases with depth in the concentrations of chloride, calcium, lithium, potassium, and rubidium indicate that reactions in the sediment column below $\sim 180$ meters are chiefly responsible for the large concentration increases in these constituents. Especially higher than expected are increases in potassium and ru-

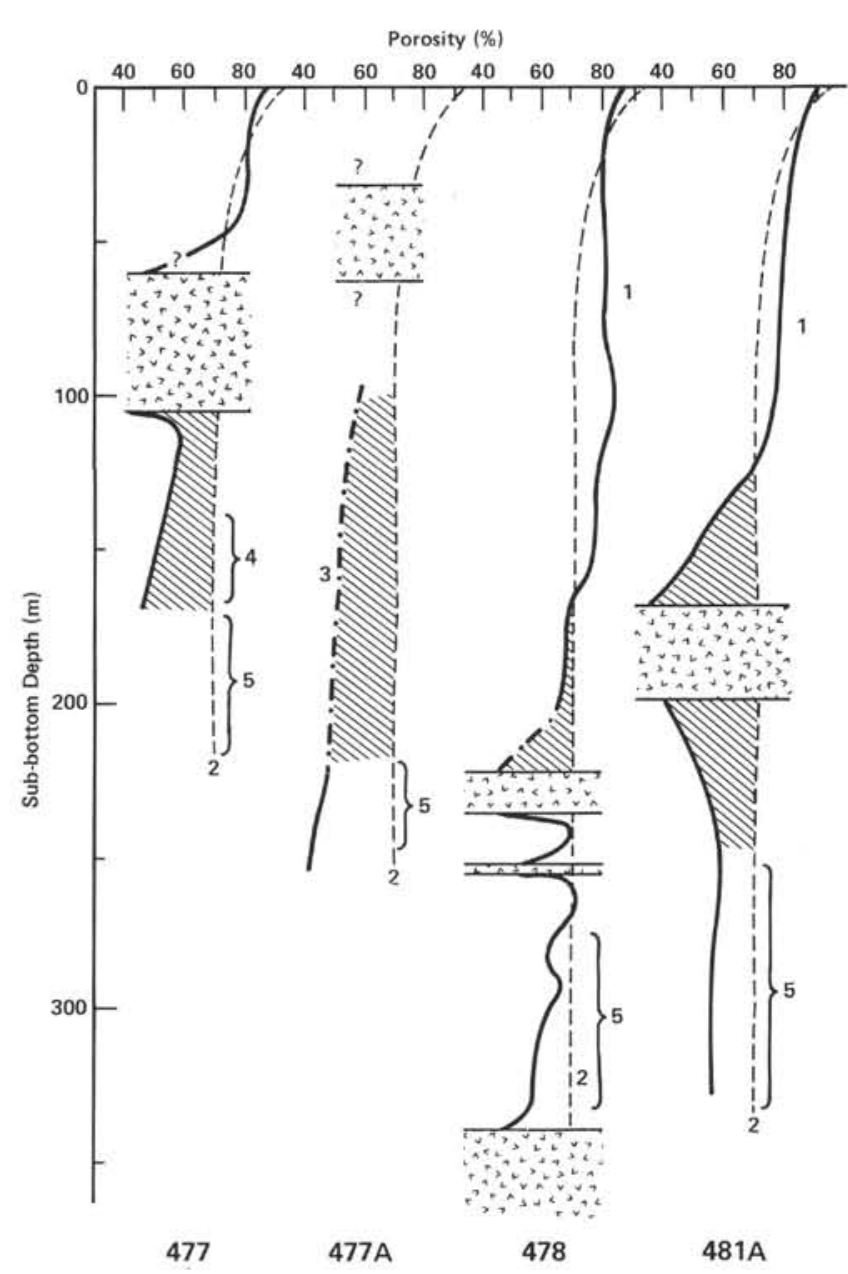

Figure 3. Sill-induced reduction of porosity (hatched areas) in Guaymas Basin sites. (1) Shipboard porosity measurements; (2) shipboard porosity, Site 479 (reference line); (3) porosity curve, deduced from density log; (4) porosity reduction due to deeper intrusions? (5) sections not considered for calculation of water loss, though some effect may be caused by compaction due to upper sill load (in Site 478 , definitely affected by lower sill).

bidium when compared with concentrations resulting from hydrothermal interactions between sea waters and basalts (Edmond et al., 1979a). This can be understood in terms of the hydrothermal interactions of sea water and interstitial water, not only with the basaltic intrusions but also with the sediments, which contain much higher concentrations of these elements than do the basalts. Indeed, at Site 477 below 180 meters, potassium has been removed almost quantitatively from the solid sedimentary phases. Increases in chloride concentrations are most likely due to removal of water into hydrated alteration phases.

Site 481 represents a different situation. At this site, the most recent hydrothermal event must have been associated with the intrusions of the sill complex between present sub-bottom depths of 170 and 200 meters. This is clearly indicated by the profiles of dissolved chloride and of dissolved rubidium and lithium, all of which show enhanced levels around the sills. Not enough time has yet elapsed to annihilate such concentration anoma- 


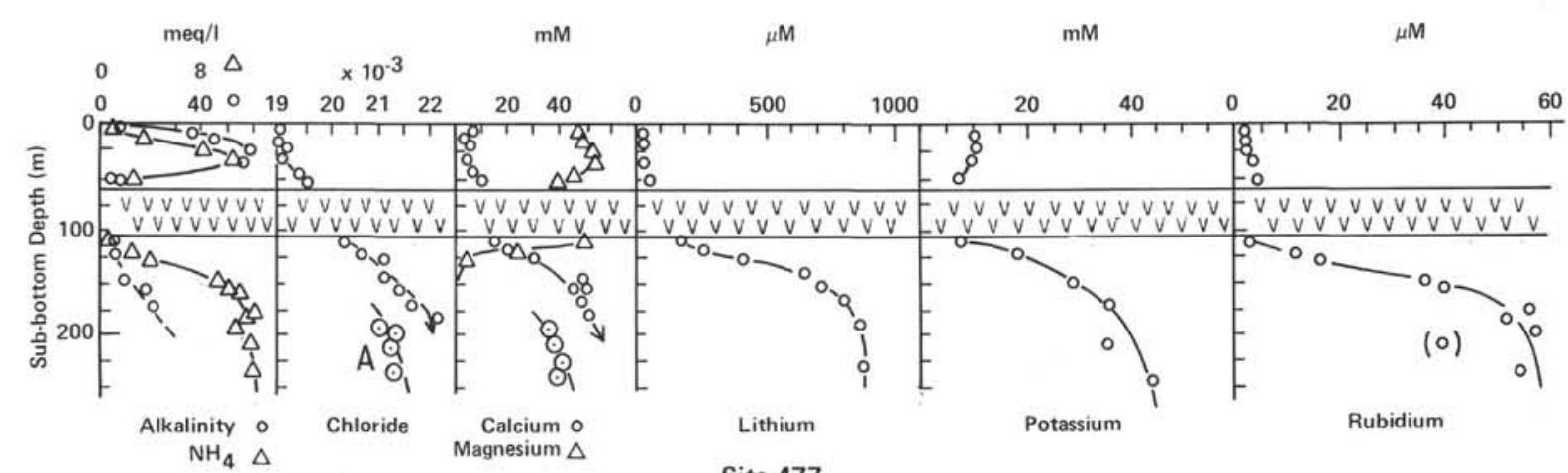

Site 477

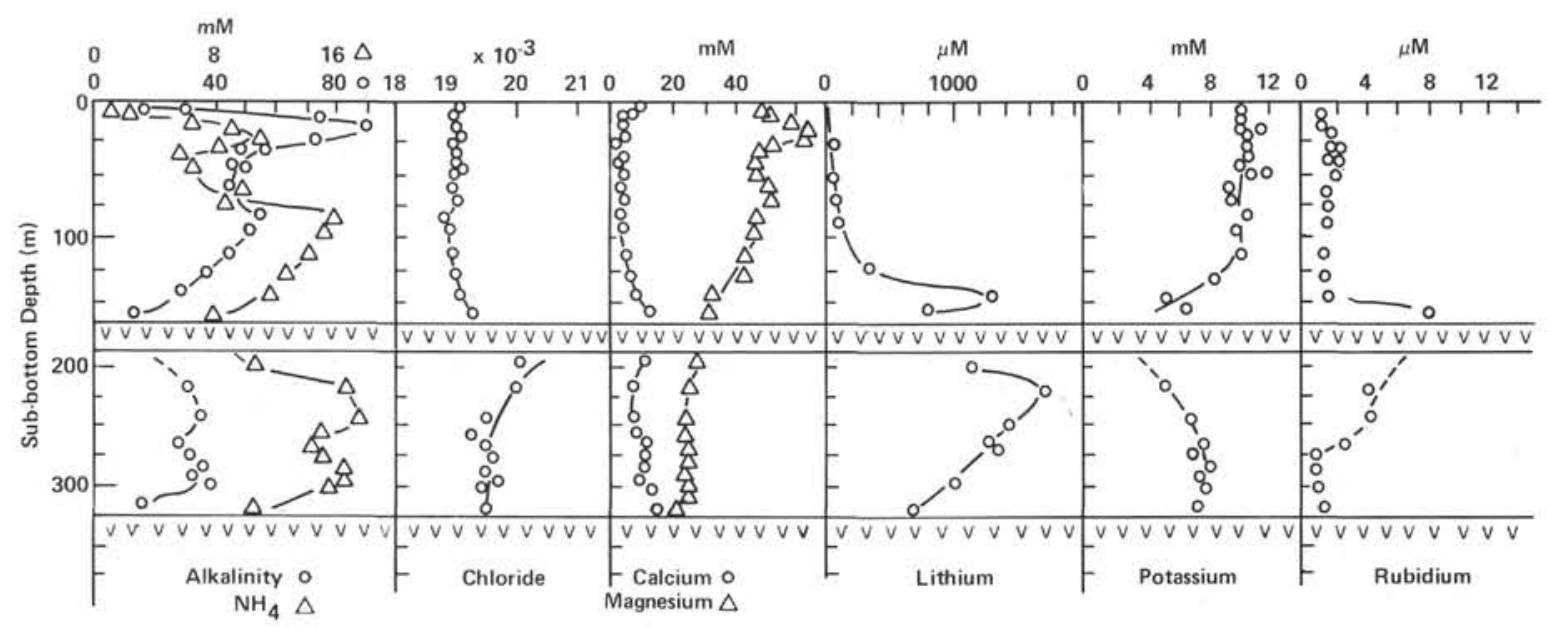

Site 481

Figure 4. Interstitial water composition Sites 477 and 481. A denotes Site 477A.

lies by diffusion and reaction processes. The sill complex has cooled down considerably since its intrusion, whence the low heat flow (4 HFU) and the decrease in dissolved potassium and lithium toward the sills. Below $75^{\circ} \mathrm{C}$ (Seyfried and Bischoff, 1979) basalt alteration will generally lead to the uptake of potassium, rather than to its release to the pore fluids. The signals in chloride, lithium, and rubidium simply indicate that the effects of the hydrothermal event have not yet decayed away by diffusional transport processes.

\section{CHEMISTRY AND MINERALOGY OF SEDIMENTS}

The bulk chemical compositions of the solid phases of the sediments of Sites 477,478 , and 481 are described in detail in the chapters of Niemitz (this volume, Pt. 2) and Gieskes et al. (this volume, Pt. 2). Mineralogical data are discussed by Kastner (this volume, Pt. 2) and Kelts (this volume, Pt. 2).

In general, two types of hydrothermal effects can be distinguished in these holes in the Guaymas Basin:

1) Contact metamorphism of the sediments as a result of basaltic sill intrusions.

2) Greenschist facies metamorphism as a result of substantial hydrothermal alteration of sediments at high temperatures $\left(>200^{\circ} \mathrm{C}\right)$.
In Table 1 the relevant mineralogical and chemical observations are summarized.

Contact metamorphism is generally associated with little change in the chemical composition of the sediments, with the exception of noticeable increases in $\mathrm{Mg} / \mathrm{Al}$ near the sill of Hole 477 , and decreases in $\mathrm{K} / \mathrm{Al}$, $\mathrm{Si} / \mathrm{Al}$, and $\mathrm{Li}$ near the upper contact with the sill in Hole 477 and perhaps in Hole 481A. The mineralogical observations described in Table 1 indicate that contact metamorphism is generally associated with temperatures below $200^{\circ} \mathrm{C}$.

Table 1. Mineralogy and chemistry of hydrothermally altered sediments.

\footnotetext{
Contact Metamorphism: Associated with sill complexes in Site 477 and 481

Above sills: Clays recrystallized to smectite; calcite recrystallized (Site $48 \mathrm{I}:-170^{\circ} \mathrm{C}$ ); Diatoms transformed to quartz: pyrite

Below sills: Same as above sills, but to lesser extents

In 481: Na-phase is analcite, indicating $\mathrm{t}<200^{\circ} \mathrm{C}$

In 477: Some K-feldspar

Chemistry (above and below sill): increase $\mathrm{Mg} / \mathrm{Al}(477)$, decrease $\mathrm{Si} / \mathrm{Al}$ (477); decrease in $\mathrm{K} / \mathrm{Al}$ (above sill 477 ); decrease in $\mathrm{Li}(477 ; 481)$

Greenschist Facies: Site 477/477A below sills (Fig. 2)

$-100 \mathrm{~m}$ : Contact metamorphism; K-feldspar result of activity below

$-120-130 \mathrm{~m}$ : Chlorite appears; K-feldspar; albite; anhydrite and gypsum; pyrite; quartz

$\sim 130-140 \mathrm{~m}$ : Appearance of epidote and sphene; chlorite increasing with depth

$-180 \mathrm{~m}$ : Layer with abundant pyrite nodules; co-occurrence pyrite and pyrrhotite be-

Layer with abundant pyrite
low indicates $\mathrm{t}-300^{\circ} \mathrm{C}$

$190-260 \mathrm{~m}$ : Dominant assemblage in greenschist facies: chlorite (iron rich)-quartz-albitesphene-epidote; nonsilicates: pyrite and pyrrhotite Chemistry: disappearance of $\mathrm{K}$; low $\mathrm{Li}, \mathrm{V}$; increased $\mathrm{Zn}$ (in Fe-sulfides?)
} 
Greenschist facies metamorphism as at Site 477 requires higher temperatures than those prevailing around sill intrusions, probably over longer time periods of hydrothermal activity than in the zones of contact metamorphism. The mineralogical observations at Site 477 present a classical sequence of hydrothermal greenschist facies. In the sediment horizons below $\sim 150$ meters, substantial hydrothermal alteration has led to the formation of the assemblage chlorite-quartz-albite-spheneepidote and to the almost complete removal of potassium from the solid phases. This assemblage, together with the occurrence of pyrite/pyrrhotite, implies temperatures of up to $300^{\circ} \mathrm{C}$ (Hoagland and Elders, 1978; Elders et al., 1979). The heat flow data obtained at Site 477 ( $>20 \mathrm{HFU}$ ) also suggest temperatures in excess of $200^{\circ} \mathrm{C}$ at these depths. Kastner (this volume, Pt. 2) estimates a temperature of $\sim 300^{\circ} \mathrm{C}$ using oxygen isotope data on the co-occurrence of chlorite-quartz. At depths of $\sim 180$ meters there occurs a layer of pyrite nodules, up to $5 \mathrm{~mm}$ in diameter. These well-crystallized pyrites are probably the result of in situ precipitation of sulfides as a result of upward-migrating hydrogen sulfide and iron-rich solutions. In the upper part of the greenschist zone, the high dissolved-potassium concentrations in the upward-advecting interstitial waters lead to the precipitation of K-feldspar between 130 meters and the sill intrusion at 100 meters. Elders et al. (1979) indicate the temperature range of the K-feldspar stability zone to be $150-300^{\circ} \mathrm{C}$.

\section{STABLE ISOTOPES}

Studies of stable isotopes have concentrated on oxygen isotopes in solid silicates and interstitial waters (Kastner, this volume, Pt. 2; Gieskes et al., this volume, Pt. 2), on strontium isotopes in bulk sediments and interstitial waters (Gieskes et al., this volume, Pt. 2) and on sulfur isotopes in the sulfides of Site 477 (Shanks and Niemitz, this volume, Pt. 2).

Oxygen isotopic data are summarized in Figure 5. As discussed by Kastner (this volume, Pt. 2) the $\delta^{18} \mathrm{O}$ value of silicates in the vicinity of the sill intrusions drop to values of approximately $10 \%$ above the sills and $12 \%$ below the sills. The oxygen isotopic composition of interstitial waters above the sills appears lower than below the sills, at least at Site 481 . This can be understood in terms of renewal of water by recharge above the sills, thus leading to lower $\delta^{18} \mathrm{O}$ in the alteration phases. The very high $\delta^{18} \mathrm{O}$ values of the interstitial waters below the sill at Site 481 indicate that the system below these sill intrusions is essentially closed.

In the zone of greenschist facies at Site $477, \delta^{18} \mathrm{O}$ values of the silicates gradually decrease to $\sim 6.5 \%$ (SMOW), values similar to those of fresh basalts. Water recovery in the deeper sections of the sediments unfortunately was poor, and we were unable to make a precise determination of the interstitial water profile of $\delta^{18} \mathrm{O}$ at Site 477. The data in Figure 5, however, suggest that relatively low values occur despite the large decrease in $\delta^{18} \mathrm{O}$ of the solid phases. This observation suggests that below the sills at Site $\mathbf{4 7 7}$ the hydrothermal system is an open system, with hydrothermally heated waters being
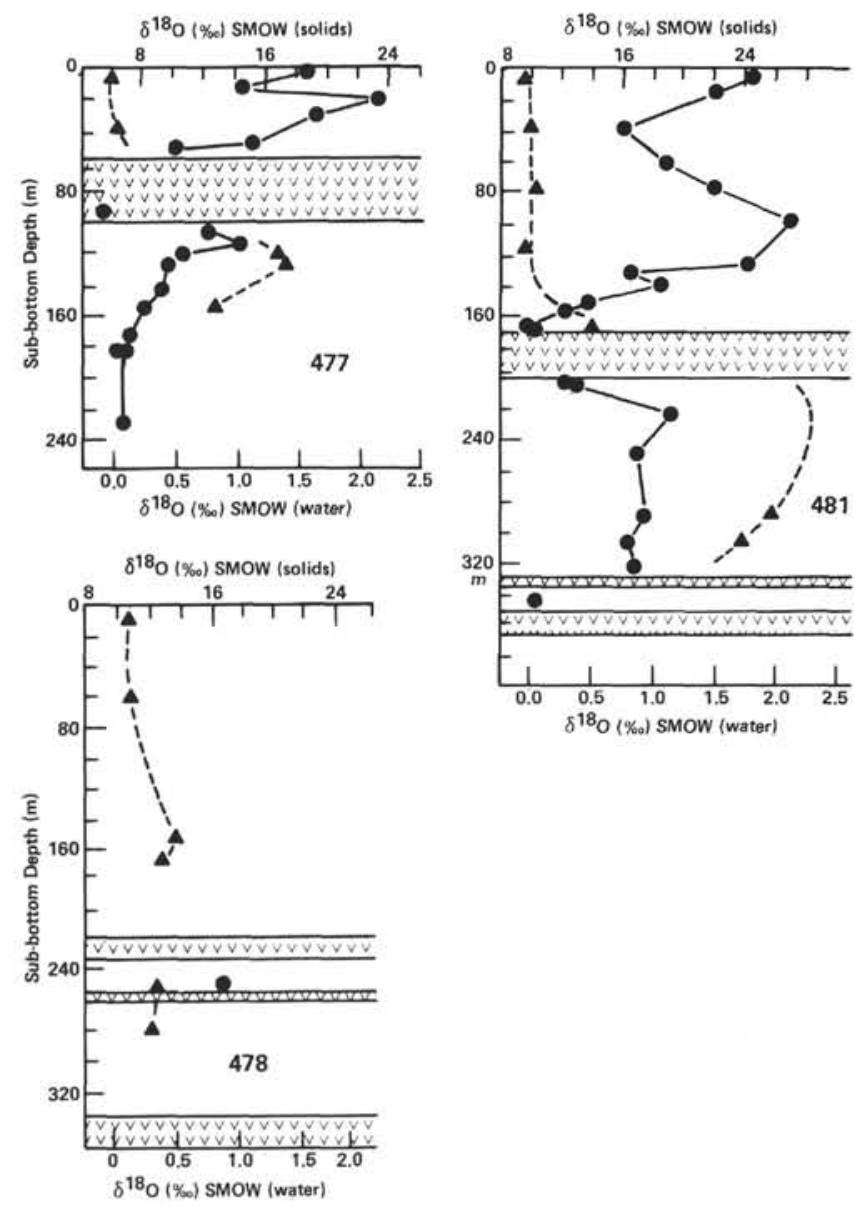

Figure $5 . \delta^{18} \mathrm{O}$ of solid silicates and interstitial waters, Sites 477, 478, and 481 . Triangles $=$ interstitial waters; circles $=$ solids.

replaced by recharge of bottom waters in the Guaymas Basin.

Data on $\delta^{18} \mathrm{O}$ of interstitial waters at Site 478 suggest slightly elevated values as a result of past hydrothermal reactions. However, diffusion processes and low-temperature alteration reactions have almost erased the originally increased $\delta^{18} \mathrm{O}$ values.

Data on the distribution of ${ }^{87} \mathrm{Sr} /{ }^{86} \mathrm{Sr}$ in the dissolved strontium of the interstitial waters are summarized in Figure 6 . The data suggest that hydrothermal interactions between interstitial waters and the sediments and/ or basalts have led to substantial equilibration with the interstitial waters. In the deeper sections of Hole 477, interstitial-water ${ }^{87} \mathrm{Sr} /{ }^{86} \mathrm{Sr}$ ratios are lower than those of the bulk solids (Gieskes et al., this volume, Pt. 2). Complete equilibration with basaltic material would lead to a ratio 0.703-0.704 in this site (cf. Menzies and Seyfried, 1979; Elderfield and Greaves, 1981; Albarede et al., 1981). Further work will be necessary to determine the relative contribution of sediments and basalts to this isotopic exchange.

Sulfur isotopic studies of sulfides in the sediments of Site 477 suggest a range, for $\delta^{34} \mathrm{~S}$, of -11.06 to $+7.31 \%$ (Shanks and Niemitz, this volume, Pt. 2). Below 170 meters, $\delta^{34} \mathrm{~S}$ values of sulfides are in the range of $5-7.31 \%$, values considered to be representative of 


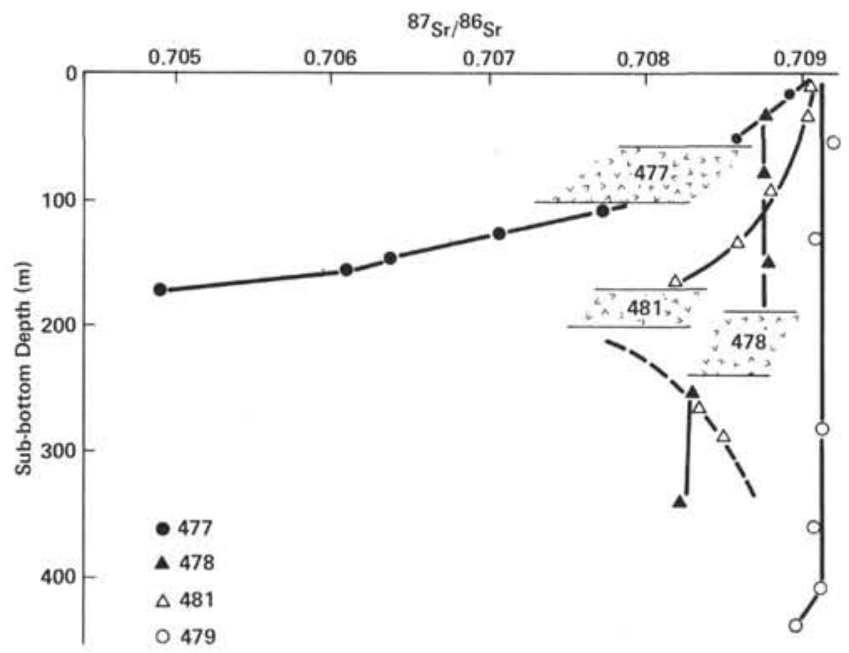

Figure 6. Strontium isotopic composition of interstitial waters, Sites 477,478 , and 481 . Site 479 on slope of Guaymas Basin (Fig. 1) is presented for reference.

hydrothermal sulfides (Ohmoto and Rye, 1979). The wide range of $\delta^{34} \mathrm{~S}$ values found at Site 477 can be understood best in terms of contributions of both hydrothermal sulfides and biogenic sulfides (Shanks and Niemitz, this volume, Pt. 2). Similarly, sulfides associated with the hydrothermal talc deposit in the northern trough (Lonsdale et al., 1980) were found to have biogenic sulfide contributions.

\section{HYDROTHERMAL SYSTEM}

Evidence from intensive heat flow surveys (Lawver et al., 1975; Williams et al., 1979; Becker, 1981) implies that zones of high heat flow in the northern and southern troughs of the Guaymas Basin are extremely limited in size. These observations have been interpreted in terms of upwelling of hydrothermal waters through the sediments along fault zones and fissures near areas in which basalt intrusions occur, as well as in terms of recharge of the hydrothermal system by advection of basin bottom waters. Lonsdale et al. (1980) investigated a sample of a hydrothermal talc deposit obtained by the submersible Seacliff in the northern trough of the Guaymas Basin and estimated that waters emanating from the hydrothermal vent associated with this deposit must have reached temperatures of $\sim 280^{\circ} \mathrm{C}$. Similarly, during dives of the submersible Alvin in January 1982, hydrothermal sulfide deposits and associated vents indicated exit temperatures of hydrothermal waters between 275 and $315^{\circ} \mathrm{C}$. That these vents do contribute substantially to the bottom waters of the Guaymas Basin has been shown from ${ }^{3} \mathrm{He}$ anomalies observed by Lupton (1979).

The information gained during Leg 64 has served mainly to clarify the nature of magmatic intrusions previously postulated to occur in the Guaymas Basin (Moore, 1973; Lawver et al., 1975). Two major types of hydrothermal systems can be distinguished; these are represented schematically in Figure 7: (1) hydrothermal activity of relatively short duration associated with sill intrusions into sediments of high porosity (Fig. 7B), and
(2) hydrothermal activity of greater longevity associated with proximate magmatic sources (Fig. 7A). In the following we wish to discuss these systems in greater detail.

Sill intrusions into wet sediments appear to be the main mechanism of new ocean floor creation in the Guaymas Basin of the Gulf of California (Einsele et al., 1980; Einsele, this volume, Pt. 2). Drilling at Sites 477, 478 , and 481 suggests that the thicknesses of such sills can be greater than 100 meters, but that generally smaller thicknesses occur, except perhaps near the magmatic sources for these intrusions. Data on porosity decreases (Fig. 3) clearly indicate that large-scale reductions occur in porosity both above and below these sill intrusions. Associated with these porosity decreases are large-scale expulsions of pore fluids, the height of the water column expelled often being in excess of the thickness of the sill intrusion (Einsele et al., 1980; Einsele, this volume, Pt. 2). Sill intrusions generally occur within 50 meters of the sediment/water interface, which is evident not only from the thickness of the porosity-reduction zone, but also from the Deep Tow records in the basin (P. Lonsdale, per. comm.). The porosity reduction does not per se require a recharge of water from the basin waters, though such recharge cannot be disproven, especially above the sill intrusions. Associated with the hydrothermal activity caused by the intrusion of the hot sills are changes in interstitial water chemistry (Figs. 4, 5, and 6), which indicate changes of the same nature as described for hydrothermal fluids associated with open-ocean spreading ridges (e.g., Edmond et al., 1979a). Differences in chemical composition are caused mainly by the involvement of sediments as well as basalts in the hydrothermal interactions. Evidence from oxygen isotopes of bulk silicates suggests moderate temperature alteration $\left(<200^{\circ} \mathrm{C}\right)$. The expelled waters would be transported out of the sediments mainly along faults and fissures on the trough floor or at the fault scarps of the troughs (Fig. 7; Einsele et al., 1980; Lonsdale et al., 1980). Exit temperatures of hydrothermal vents associated with these sill intrusions should be moderate, though sulfides may still be associated with possible hydrothermal deposits. When magnesium removal from the heated interstitial waters is incomplete, the expelled fluids, which would contain high concentrations of dissolved silica, could lead to deposition of magnesium silicates. However, the talc deposit described by Lonsdale et al. (1980) implies exit temperatures above $280^{\circ} \mathrm{C}$, and should, therefore, be associated with the second type of hydrothermal activity.

In the vicinity of more permanent heat sources, for example near magma chambers or feeder dikes, it is possible to develop hydrothermal systems in which recharge by bottom waters plays an important role. High temperatures in the sediments will be reached and the seat of hydrothermal activity will be located at greater depths than the depth at which sill intrusions generally occur. Site 477 is a typical example of this case. The sills in Holes 477 and 477A are essentially cooled off and are not the cause of the observed high heat flow at this site. Instead, the sill complex of this site serves in many ways as a cap rock for the hydrothermal system, thus causing 


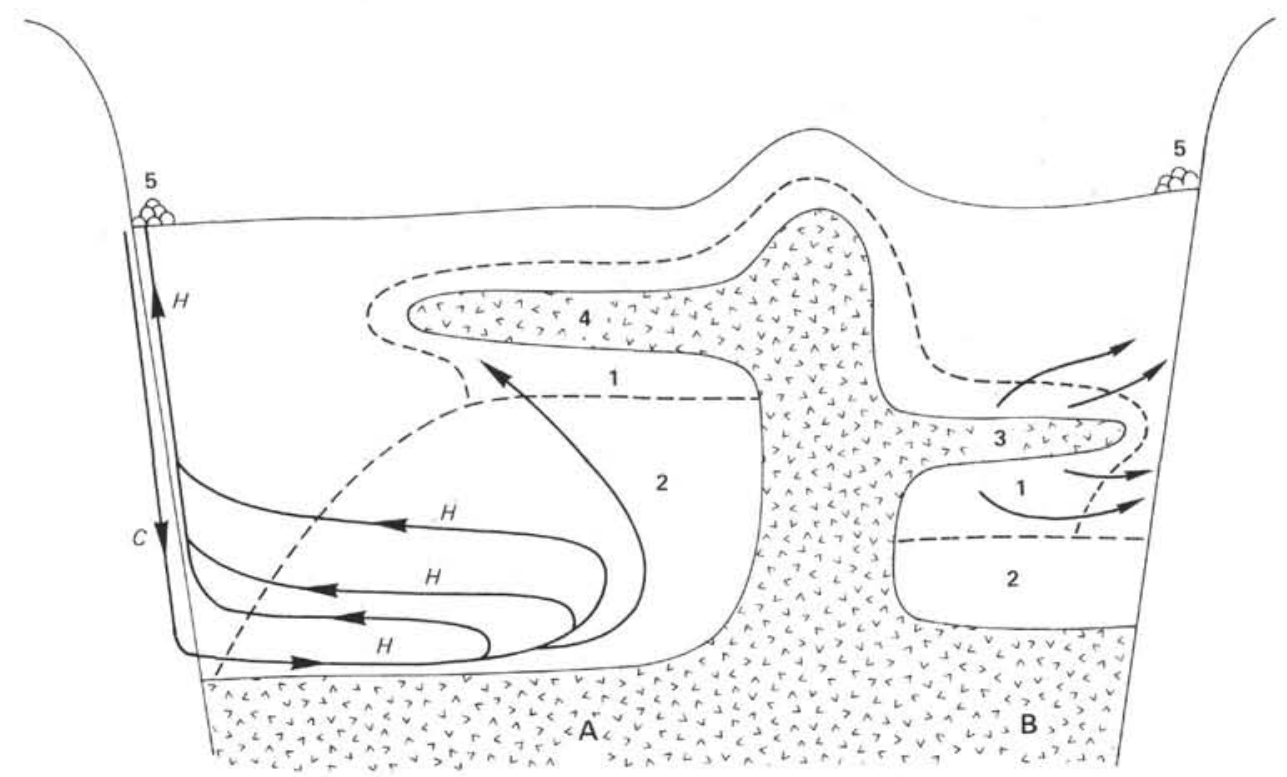

Figure 7. Schematic version of hydrothermal systems associated with Sites 477 and 481 . (1) Porosities affected mostly by uppermost sill intrusions; (2) porosities affected by older sill intrusions and/or continued hydrothermal activity at greater depths; (3) sill intrusions of nature described for Site 481 (Einsele et al., 1980); (4) cooled sill (Site 477) acting as lid on deeper hydrothermal system; (5) Hydrothermal deposits on basin floor: A, model for Site 477; B, model for Site 481 . H $=$ hot water advected through sediments and fault zones, $\mathrm{C}=$ cold water advected down through fault zones.

the possible circulation pattern presented in Figure 7A. Site $\mathbf{4 7 7}$ is located between two elevated structures in the southern trough of the basin (Lonsdale, pers. comm.), which are probably due to the large accumulation of basaltic material of relatively young age (Lonsdale, pers. comm.). These hills are probably related to the formation of the sills in Holes 477 and 477A. Lonsdale (pers. comm.) also indicates the presence of fault zones near Hole $477 \mathrm{~A}$. We postulate that a magmatic source below Site 477 has been active over a considerable period of time, thus allowing the advanced state of hydrothermal alteration of the sediments. The zone of hydrothermal alteration is at least 100 meters thick. We postulate that the return flux of hydrothermal waters to conduits such as faults occurs mainly in the lower parts of Site 477. The temperatures of $280-315^{\circ} \mathrm{C}$ for exiting fluids recently observed from the submersible Alvin in this area imply considerably large fluxes of water. At these high temperatures, the emanating water will presumably be enriched in sulfides and trace metals, which then can lead to sulfide deposition. The sources of these sulfides and trace metals may be located both in the basalts (evident from ${ }^{3} \mathrm{He}$ anomalies; Lupton, 1979) and in the sediments. Waters advecting through the sediments at slower rates, that is, at depths less than 180 meters at Site 477 , will lead to the deposition of sulfides in the sediments as well as to the formation of K-feldspars near the upper sill complex.

\section{CONCLUSION}

Drill sites in the Guaymas Basin in the Gulf of California demonstrate that during the initial stage of opening of some ocean basins, basaltic magma forming new oceanic basement intrudes as sills into rapidly deposited soft sediments, creating a basement quite different from the normal ophiolite model.

Two types of hydrothermal systems can be recognized:

1) Hydrothermal activity associated with basaltic sill intrusions at relatively shallow depths $(<50 \mathrm{~m})$ into highly porous sediments. Associated with this activity are contact metamorphism (recrystallization of clays, dissolution of opaline silica; recrystallization of carbonates) and chemical changes in interstitial waters (increases in lithium, rubidium, potassium, and $\delta^{18} \mathrm{O}$; decreases in magnesium and ${ }^{87} \mathrm{Sr} /{ }^{86} \mathrm{Sr}$ ) and in the solid phases (decreases in $\mathrm{K} / \mathrm{Al}, \mathrm{Li}, \delta^{18} \mathrm{O}$ of silicates; increases in $\mathrm{Mg} / \mathrm{Al}$ ). Isotopic evidence on recrystallized carbonates and relatively high $\delta^{18} \mathrm{O}$ values of recrystallized silicates indicate that temperatures $>100^{\circ} \mathrm{C}$ and $<200^{\circ} \mathrm{C}$ are involved in this hydrothermal activity.

2) Hydrothermal activity associated with large-scale magmatic intrusions at greater depths in the sediments. In this case hydrothermal activity leads to substantial thermal alteration of sediments (greenschist facies), and mass-balance considerations of oxygen isotopes in bulk silicates and interstitial waters lead to the conclusion that these alteration reactions must occur in an open system at temperatures of approximately $300^{\circ} \mathrm{C}$. Recharge of basin bottom waters and discharge of heated fluids occur through fault zones, with sills acting as lids on these hydrothermal systems, thus forcing fluid flow in lateral directions toward faults. At locations of such hydrothermal activity, fluids emanating from faults and fissures will lead to the buildup of hydrothermal deposits recently observed in the southern trough by the submersible Alvin. 


\section{REFERENCES}

Albarede, F., Michard, A., Minster, J. F., and Michard, G., 1981. ${ }^{87} \mathrm{Sr} /{ }^{86} \mathrm{Sr}$ ratios in hydrothermal waters and deposits from the East Pacific Rise at $21^{\circ} \mathrm{N}$. Earth Planet. Sci. Lett., 55:229-236.

Anderson, R. N., Hobart, M. A., and Langseth, M. G., 1979. Geothermal convection through oceanic crust and sediments in the Indian Ocean. Science, 204:828-830.

Anderson, R. N., Langseth, M. G., and Sclater, J. G., 1977. The mechanism of heat transfer through the floor of the Indian Ocean. J. Geophys. Res., 82:3391-3409.

Baker, E. W., Huang, W. Y., Rankin, J. G., Castaño, J. R., Guinn, J. R., and Fuex, A. N., 1978. Electron paramagnetic resonance study of thermal alteration of kerogen in deep-sea sediments by basaltic sill intrusion. In Lancelot, Y., Seibold, E., et al., Init. Repts. DSDP, 41: Washington (U.S. Govt. Printing Office), 839-847.

Becker, K., 1981. Heat flow studies of spreading center hydrothermal processes [Ph.D. dissert.]. University of California, San Diego.

Bischoff, J. L., 1969. The Red Sea geothermal deposits: Their mineralogy, chemistry, and genesis. In Degens, E. T., and Ross, D. (Eds.), Hot Brines and Recent Heavy Metal Deposits: New York (Springer Verlag).

Bischoff, J. L., and Dickson, F. W., 1975. Seawater-basalt interaction at $200^{\circ} \mathrm{C}$ and 500 bars: Implications as to the origin of sea floor heavy metal deposits and regulation of seawater chemistry. Earth Planet. Sci. Lett. 25:385-397.

Boström, K., and Peterson, M. N. A., 1965. Precipitates from hydrothermal exhalations on the East Pacific Rise. Econ. Geol., 61 $1258-1265$.

Corliss, J. B., Dymond, J., Gordon, L. I., Edmond, J. M., Von Herzen, R. P., Ballard, R. D., Green, K., Williams, D., Bainbridge, A. Crane, K., van Andel, Tj. H., 1979. Submarine thermal springs on the Galapagos Rift. Science, 203:1073-1083.

Edmond, J. M., Craig, H., Gordon, L. I., and Holland, H. D., 1979a. Chemistry of hydrothermal waters at $21^{\circ} \mathrm{N}$ on the East Pacific Rise. Trans. Am. Geophys. Union, 60:864.

Edmond, J. M., Measures, C., McDuff, R. E., Chan, L. H., Collier, R., and Grant, B., 1979b. On the formation of metal-rich deposits at ridge crests. Earth Planet. Sci. Lett., 46:1-18.

Edmond, J. M., Measures, C., Mangum, B., Grant, B., Sclater, F. R., 1979c. Ridge crest hydrothermal activity and the balances of the major and minor elements in the ocean: The Galapagos data. Earth Planet. Sci. Lett., 46:19-30.

Einsele, G., Gieskes, J., Curray, J., Moore, D., Aguayo, E., Aubry, M.-P., Fornari, D., Guerrero, J., Kastner, M., Kelts, K., Lyle, M., Matoba, M., Molina-Cruz, A., Niemitz, J., Rueda, J., Saunders, A., Schrader, H., Simoneit, B., and Vacquier, V., 1980. Intrusion of basaltic sills into highly porous sediments, and resulting hydrothermal activity. Nature, 283:441-445.

Elderfield, H., and Greaves, M., 1981. Strontium isotope geochemistry of Icelandic geothermal systems and implications for seawater chemistry. Geochim. Cosmochim. Acta, 45:2201-2212.

Elders, W. A., 1979. The geological background of the geothermal fields of the Salton Trough. Guide Book, Field Trip 7, University of California, Riverside, UCR/IGPP-79/23:1-19.

Elders, W. A., Hoagland, J. R., McDowell, S. D., and Cobo, J. M., 1979. Hydrothermal mineral zones in the geothermal reservoir of Cerro Prieto. Guide Book, Field Trip 7, University of California, Riverside, UCR/IGPP-79/23:36-43.

Francheteau, J., Choukroune, P., Juteau, T., Séguret, M., Ballard, R. D., Fox, P. J., Normark, W., Carranza, A., Cordoba, D., Guerrero, J., Rangin, C., Bougault, H., Cambon, P., and Hekinian, R., 1979. Massive deep sea sulphide deposits discovered by submersible on the East Pacific Rise. Project RITA, $21^{\circ} \mathrm{N}$. Nature, 277:523-528.

Hajash, A., 1975. Hydrothermal processes along mid-ocean ridges: An experimental investigation. Contrib. Mineral. Petrol., 53: 205-226.

Haymon, R. M., and Kastner, M., 1980. Hot spring on the East Pacific Rise $21^{\circ} \mathrm{N}$ : Preliminary description of mineralogy and genesis. Earth Planet. Sci. Lett. 53:363-381.

Hoagland, J. R., and Elders, W. A., 1978. Hydrothermal mineralogy and isotopic geochemistry in the Cerro Prieto geothermal field,
Mexico. I. Hydrothermal mineral zonation. Geol. Resourc. Council Trans., 2:283-286.

Kastner, M., and Gieskes, J. M., 1981. Hydrothermal activity in the Guaymas Basin, Gulf of California. Trans. Am. Geophys. Union, 62:914.

Lawver, L. A., Williams, D. L., and Von Herzen, R. P., 1975. A major geothermal anomaly in the Gulf of California. Nature, 257: 23-28.

Lister, C. R. B., 1972. On the thermal balance of a mid-ocean ridge. Geophys. J., 26:515-535.

Lonsdale, P., 1978. Submersible exploration of Guaymas Basin. SIO Ref. 78-1 (Reports, Scripps Institution of Oceanography).

Lonsdale, P. F., Bischoff, J. L., Burns, V. M., Kastner, M., and Sweeney, R. E., 1980. A high-temperature hydrothermal deposit on the sea bed at a Gulf of California spreading center. Earth Planet. Sci. Lett., 49:8-20.

Lupton, J. E., 1979. Helium-3 in the Guaymas Basin: Evidence for injection of mantle volatiles in the Gulf of California. J. Geophys. Res., 84:7446-7452.

Menzies, M., and Seyfried, W. E., 1979. Basalt-seawater interaction: Trace element and strontium isotopic variations in experimentally altered glassy basalt. Earth Planet. Sci. Lett., 44:463-472.

Moore, D. G., 1973. Plate-edge deformation and crustal growth, Gulf of California structural province. Geol. Soc. Am. Bull., 84: 1883-1906.

Moore, W. S., and Vogt, P. G., 1976. Hydrothermal manganese crusts from two sites near the Galapagos spreading axis. Earth Planet. Sci. Lett., 29:349-356.

Mottl, M. J., and Holland, H. D., 1978. Chemical exchange during hydrothermal alteration of basalt by seawater. I. Experimental results for major and minor components of seawater. Geochim. Cosmochim. Acta, 42:1103-1115.

Natland, J. H., Rosendahl, B., Hekinian, R., Dmitriev, Y., Fodor, R. V., Goll, R. M., Hoffert, M., Humphris, S. M., Mattey, D. P., Petersen, N., Roggenthen, W., Schrader, E. L., Srivastava, R. K., and Warren, N., 1979. Galapagos hydrothermal mounds: Stratigraphy and chemistry revealed by Deep Sea Drilling. Science, 204: 613-616.

Ohmoto, H., and Rye, R. O., 1979. Isotopes of sulfur and carbon. In Barnes, H. L. (Ed.), Geochemistry of Hydrothermal Ore Deposits (2nd ed.): New York (Wiley-Interscience), pp. 509-567.

Sclater, J. G., and Klitgord, K. D., 1973. A detailed heat flow, topographic, and magnetic survey across the Galapagos spreading center at $86^{\circ}$ W. J. Geophys. Res., 78:6951-6975.

Scott, M. R., Scott, R. B., Rona, P. A., Butler, L. W., and Nalwalk, A. J., 1974. Rapidly accumulating manganese deposits from the median valley of the Mid-Atlantic Ridge. Geophys. Res. Lett., $1: 355-358$.

Seyfried, W. E., and Bischoff, J. L., 1977. Hydrothermal transport of heavy metals by seawater: The role of seawater basalt ratio. Earth Planet. Sci. Lett., 34:71-78.

1979. Low temperature basalt alteration by seawater: An experimental study at $70^{\circ} \mathrm{C}$ and $150^{\circ} \mathrm{C}$. Geochim. Cosmochim. Acta, 43:1937-1947.

Simoneit, B. R. T., Brenner, S., Peters, K. E., and Kaplan, I. R., 1981. Thermal alteration of Cretaceous black shale by diabase intrusions in the Eastern Atlantic-II. Effects on bitumen and kerogen. Geochim. Cosmochim. Acta, 45:1581-1602.

Spiess, F. N., MacDonald, K. C., Atwater, T., Ballard, R., Carranza, A., Cordoba, D., Cox, C., Diaz Garcia, V. M., Francheteau, J., Guerrero, J., Hawkins, J., Haymon, R., Hessler, R., Juteau, T., Kastner, M., Larson, R., Luyendyk, B., Macdougall, J. D., Miller, S., Normark, W., Orcutt, J., Rangin, C., 1980. Hot springs and geophysical experiments on the East Pacific Rise. Science, 207:1421-1433.

Williams, D. L., Becker, K., Lawver, L. A., and Von Herzen, R. P., 1979. Heat flow at the spreading centers of the Guaymas Basin, Gulf of California. J. Geophys. Res., 84:6757-6769.

Williams, D. L., Von Herzen, R. P., Sclater, J. G., and Anderson, R. N., 1974. The Galapagos spreading center: Lithospheric cooling and hydrothermal circulation. Geophys. J., 38:587-608.

Wolery, T. J., and Sleep, N. H., 1976. Hydrothermal circulation and geochemical flux at mid-ocean ridges. J. Geol., 84:249-275. 